\title{
Eleven-year results on soft and durum wheat crops grown in an organic and in a conventional low input cropping system
}

\author{
Paolo Benincasa, Michela Farneselli, Giacomo Tosti, Umberto Bonciarelli, \\ Maria Chiara Lorenzetti, Marcello Guiducci \\ Dipartimento di Scienze Agrarie, Alimentari ed Ambientali, Università degli Studi \\ di Perugia, Italy
}

\begin{abstract}
Eleven-year results on yields and apparent balances of organic matter and nitrogen $(\mathrm{N})$ are reported for soft and durum wheat crops grown in the BIOSYST long-term experiment for the comparison between an organic and a conventional low-input system in Central Italy. The $\mathrm{N}$ supply to organic wheat consisted of $40 \mathrm{~kg} \mathrm{~N} \mathrm{ha}^{-1}$ as poultry manure plus the supposed residual $\mathrm{N}$ left by green manures carried out before the preceding summer vegetable, while the $\mathrm{N}$ supply to conventional wheat consisted of $80 \mathrm{~kg} \mathrm{~N} \mathrm{ha}^{-1}$ as mineral fertilisers, split in two applications of $40 \mathrm{~kg} \mathrm{ha}^{-1}$ each, at tillering and preshooting. In every year, above ground biomass and $\mathrm{N}$ accumulation
\end{abstract}

Correspondence: Paolo Benincasa, Dipartimento di Scienze Agrarie, Alimentari ed Ambientali, Università degli Studi di Perugia, Borgo XX Giugno 74, 06121 Perugia, Italy.

Tel.: +39.075.585.6325 - Fax: +39.075 .585 .6344 .

E-mail: paoloben@unipg.it

Key words: Long-term experiment; biomass; yield; nitrogen; poultry manure; residue; apparent balance.

Acknowledgements: we gratefully acknowledge Mr. Daniele Luchetti together with all workers of our Experimental Station in Papiano for the constant skilful support in running the BIOSYST LTE. Across years, the BIOSYST LTE was funded by: i) Project BIOSYST, 1999-2002, University of Perugia; ii) Project FISR-SIMBIOVEG, 2007-2009, Italian Ministry of University and Research (MiUR); iii) Project NITBIO, 2010-2012, Italian Ministry of Agriculture and Forestry Policy (MiPAAF); iv) Project PRIN-IC-FAR, 20132015, MiUR

Conference presentation: SIA XLIV Congress, Bologna, 2015.

Received for publication: 1 December 2015

Revision received: 4 February 2016.

Accepted for publication: 4 February 2016.

(C) Copyright P. Benincasa et al., 2016

Licensee PAGEPress, Italy

Italian Journal of Agronomy 2016; 11:726

doi:10.4081/ija.2016.726

This article is distributed under the terms of the Creative Commons Attribution Noncommercial License (by-nc 4.0) which permits any noncommercial use, distribution, and reproduction in any medium, provided the original author(s) and source are credited. of each wheat species, including weeds, and the partitioning between grain yield and crop residues were determined. Apparent dry matter and $\mathrm{N}$ balances were calculated at the end of each crop cycle by taking into account the amounts of dry matter and $\mathrm{N}$ supplied to the system as fertilisers, and those removed with grain yield.

Soft wheat yielded more than durum wheat. For both species, grain yield and protein content were more variable across years and generally lower in the organic than in the conventional system. In both systems, grain yield of both species resulted negatively correlated with fall-winter rainfall, likely for its effect on soil $\mathrm{N}$ availability. Both species caused a lower return of biomass and a higher soil $\mathrm{N}$ depletion in the organic than in the conventional system. Our experiment confirmed that winter wheat can help exploit the soil $\mathrm{N}$ availability and reduce $\mathrm{N}$ leaching in fall winter, especially after summer vegetables, but in stockless or stock-limited organic systems it needs to be included in rotations where soil fertility is restored by fall winter green manures to be carried out before summer crops.

\section{Introduction}

Long-term experiments (LTE) are useful to understand and compare long-term effects of organic and conventional systems on crop productivity and the environment (Fließbach et al., 2006; ThorupKristensen et al., 2012; Wortman et al., 2012; Mayer et al., 2015). For this reason, we started the BIOSYST LTE in 1996, to compare an organic rotational system and a conventional low-input system in Central Italy. The results published till now concerned dynamics and balances of organic matter and nutrients in the soil (Boldrini et al., 2007, 2008) and weed dynamics (Graziani et al., 2012) for each system as a whole, and detailed results for specific crops like maize (Zea mays L.) and tomato (Lycopersicon esculentum L.) (Farneselli et al., 2013), and muskmelon (Cucumis melo var. reticulatus L.) (Farneselli et al., 2015). As usual for Mediterranean cropping systems, the BIOSYST rotation include soft and durum winter wheat (Triticum aestivum L. and Triticum durum L., respectively), which actually represent the major rainfed cereals in Italy. In the Mediterranean environment, the productivity of winter cereals is strictly related to the management of $\mathrm{N}$ availability in fall-winter (Watson et al., 2002) and weed control (Graziani et al., 2012). Contrarily to maize, tomato and melon, winter wheat cannot be fertilised by fall-winter green manuring. Thus, adequate $\mathrm{N}$ availability for this crop in organic system has to be achieved by an appropriate crop rotation and the direct supply of organic fertilisers (Hawkesford, 2014). In Mediterranean stockless contexts, however, 
organic fertilisers represent extra-farm inputs, thus they can be little available and anyway their use should be limited in the view of pursuing the system self-sufficiency as a fundament of organic farming. For this reason, wheat should maximise the exploitation of the residual $\mathrm{N}$ availability deriving from the green manuring carried out before the preceding summer cash crop (Thorup-Kristensen et al., 2012; Mayer et al., 2015). This should also contribute to limit the risk of $\mathrm{N}$ loss in winter, which is a key aspect to increase environmental sustainability of the system (Gabriel et al., 2012).

Many experiments all over the world dealt with organically $v s$ conventionally grown wheat, but literature becomes less copious for stockless systems in Mediterranean environments. Moreover, Mediterranean environments may differ much from each other, and this hinders the drawing of general pictures. For example, the Italian peninsula, which overall falls within the Mediterranean area, may have much different temperature and rainfall regimes passing from the South to the North and from the West coast to the inland piedmont hills and plains of Apennine regions, to the East coast. Two other wheat-based LTEs have been carrying out in Central Italy, which are comparable to our one (Migliorini et al., 2014; Mazzoncini et al., 2015). Apart from location peculiarity of each one (west coast plain with sandy soils and mild winter for Mazzoncini et al., 2015; inner hill with clay soil and colder winter for Migliorini et al., 2014), both include only arable crops in the rotation. The peculiarity of BIOSYST LTE is that it is located in an inland plain of Central Italy, with clay-loam soil and cold winter, and the rotation include summer vegetables with the goal to increase the economic sustainability of the system and optimise the use of resources. Hence, the aim of this work, which is to evaluate the grain yield and apparent biomass and $\mathrm{N}$ balances of soft and durum wheat rotated to several arable and vegetable cash crops in a long-term experiment conceived to compare an organic and a conventional low-input system in an inland plain of Central Italy.

\section{Materials and methods}

The BIOSYST LTE is located at the Experimental Station of Agronomy and Field Crops (FIELDLAB) in Papiano (Central Italy, 15 $\mathrm{km}$ south from Perugia, middle Tiber Valley, $43^{\circ} \mathrm{N}, 12.3^{\circ} \mathrm{E}, 165 \mathrm{~m}$ a.s.l.). The organic system (ORG) (EU reg. 2092/91) and the conventional low-input system (LOW) (EU reg. 2078/92) are laid down in two contiguous fields originally homogeneous for soil properties [clay loam, with same initial contents of soil organic matter, total nitrogen $(\mathrm{N})$, available phosphorus $(\mathrm{P})$ and exchangeable potassium (K)] (European Commission, 1991, 1992). The BIOSYST started in 1996. Details on the general design of the experiment and on the period between 1996 and 2002 are reported in Farneselli et al. (2015).

Starting from 2002, a 6-year rotation was adopted with a same basic sequence of cash crops for both systems: summer cereal (grain maize) - industrial vegetable (processing tomato) - winter cereal (durum wheat) - grain legume (in most cases: faba bean, Vicia faba var. minor L.; or common pea, Pisum sativum L.) - summer vegetable (in most cases: melon; or sweet pepper, Capsicum annuum L.) - winter cereal (soft wheat). In order to reproduce the steady-state running of the basic 6 -year rotation in a farm and test all the six crops of the sequence in each year, six different orderings were realised for both ORG and LOW field, each ordering starting with a different crop of the sequence.

This work reports data on soft wheat and durum wheat cultivated between 2002/2003 and 2012/2013, always after summer vegetables.
The main differences between the two systems concerned $\mathrm{N}$ fertilisation management and crop protection (Farneselli et al., 2015). In particular, $\mathrm{N}$ fertilisation for summer crops in ORG relied on previous fall-winter green manures with vetch-barley intercrops (field pea-barley from 2011 onwards), integrated in case by organic fertilisers. As far as wheat is concerned, the crop in ORG was fertilised by pre-sowing application of pelleted poultry manure [carbon (C):N:P:K=47:4:4:3] at the rate of $40 \mathrm{~kg} \mathrm{~N} \mathrm{ha}^{-1}$; the crop in LOW was fertilised by mineral fertilisers (urea or ammonium nitrate) at the same rate of $\mathrm{ORG}$ for $\mathrm{P}$ and $\mathrm{K}$, but at double rate for $\mathrm{N}$ (i.e., $80 \mathrm{~kg} \mathrm{~N}$ $\mathrm{ha}^{-1}$ ), split half at tillering (within the first half of February) and half before shooting (around mid-march). The use of a lower $\mathrm{N}$ rate in ORG was adopted in view of the expected residual $\mathrm{N}$ availability provided by the green manures carried out before the preceding summer crop.

Weed control was mechanical in ORG, chemical (by post-emergence applications) in LOW. Pest and disease control was never necessary for wheat in both systems. Other agronomic practices (cultivar, sowing dates and densities) were the same in both systems.

In every year, above ground biomass and $\mathrm{N}$ accumulation of wheat, including weeds, and the partitioning between grain yield and crop residues (including weeds) were determined at final harvest by plant samplings and analysis of organic $\mathrm{N}$ concentration in the dry matter (Kjeldhal method). In particular, at harvest time, $1.8 \mathrm{~m}^{2}$ per plot were sampled. Biomass partitioning was then determined on sub-samples. Apparent dry matter and $\mathrm{N}$ balances were calculated at the end of each crop cycle in analogy with Farneselli et al. (2013, 2015), according to the following equations:

$$
\Delta \mathrm{DM}=\mathrm{DM}_{\mathrm{OF}}+\mathrm{DM}_{\mathrm{W}}-\mathrm{DM}_{\mathrm{GY}}
$$

where:

$\triangle \mathrm{DM}=$ apparent variation of dry matter in the system;

$\mathrm{DM}_{\mathrm{OF}}=$ dry matter from organic fertilisers;

$\mathrm{DM}_{\mathrm{W}}=$ above ground dry matter from wheat (including weeds);

$\mathrm{DM}_{\mathrm{GY}}=$ dry matter removed from the field with grain yield;

$$
\Delta \mathrm{N}=\mathrm{N}_{\mathrm{F}}-\mathrm{N}_{\mathrm{GY}}
$$

where:

$\Delta \mathrm{N}=$ apparent variation of $\mathrm{N}$ in the system (i.e., residual $\mathrm{N}$ in the soil);

$\mathrm{N}_{\mathrm{F}}=$ fertiliser- $\mathrm{N}$;

$\mathrm{N}_{\mathrm{GY}}=\mathrm{N}$ removed from the field with grain yield.

The dry biomass and $\mathrm{N}$ accumulated in roots was not taken into account for apparent balances, in analogy with Farneselli et al. $(2013,2015)$ and to avoid input of uncertainties, because it cannot be excluded that root depth and biomass differ in organic and conventional systems (Thorup-Kristensen et al., 2012).

The $\mathrm{N}$ use efficiency (NUE) of soft and durum wheat was calculated as the ratio between the grain yield dry matter and the fertiliser$\mathrm{N}$ rate supplied to the crop.

Rainfall and temperature data during every wheat-growing season were recorded by an automatic weather station inside the experimental site.

\section{Results}

Rainfalls were very variable across years (Figure 1A) and, in particular, the rainfall between November and February ranged from 134 
$\mathrm{mm}$ (2012) to $574 \mathrm{~mm}$ (2013). In 2005, in spite of a normal winter rainfall a heavy flooding event occurred at the end of December, with prolonged water stagnation, which depressed crop yield. Minimum and maximum temperatures (Figure 1B) were never limiting either for soft wheat or durum wheat.

The grain yield of both species varied across years (Figure 2A), but was higher and less variable in soft than in durum wheat. Moreover the grain yield was more variable and generally lower in ORG than in LOW, about $-1.5 \mathrm{t} \mathrm{ha}^{-1}$ year-1 on average over all years for both species (corresponding to $-25 \%$ for soft wheat and $-31 \%$ for durum wheat). Both species in both systems gave high yield in 2007 and 2012, low yield in 2005 and 2013. In 2008 the yield was very low only in durum wheat due to low plant density caused by accidental use of low quality seed.

The protein content of grains (Figure 2B) varied across years for both species and in both systems, but effects were not univocal. However, the protein content of durum wheat was higher than $12 \%$ (w:w) in five years out of eleven in LOW and only in two years in ORG. For both crops in both systems crop yield resulted negatively correlated to the rainfall between November and February, and the correlation was quite good when excluding above-mentioned outliers of 2005 for both species (due to flooding) and 2008 for durum wheat (due to low quality seed) (Figure 3 ).

The amount of biomass incorporated into the soil (i.e., that from wheat straw plus weeds and organic fertilisers) was generally higher in LOW than in ORG for both crops, with an average $+1.4 \mathrm{t} \mathrm{ha}^{-1}$ year-1 $(+20 \%)$ for soft wheat and $+1.9 \mathrm{t} \mathrm{ha}^{-1}$ year-1 $\left.^{-1}+35 \%\right)$ for durum wheat (Figure 4).

The apparent delta $\mathrm{N}$ (i.e., fertiliser- $\mathrm{N}$ minus $\mathrm{N}$ removed with grains) was generally negative for both crops and lower in ORG than in LOW ( $-37 \%$ for soft wheat and $-12 \%$ for durum wheat, on average over all years) (Figure 5).

The NUE showed much wider variations across years in ORG, but on the average it was higher in ORG for both crops $(+51 \%$ for soft wheat and $+38 \%$ in durum wheat) (Figure 6 ).

\section{Discussion}

The variability of season rainfall and temperature across the eleven experimental years (Figure 1) supports the idea that an adequate evaluation of crop suitability in organic $v s$ conventional systems can be drawn only by LTE, especially in case of rainfed crops like winter wheat, where water and $\mathrm{N}$ availability in the soil is much affected by season weather. Moreover, the occurrence of heavy rainfall events can further affect crop performance in case of flooding, as in 2004/2005, and these adverse conditions are expected to become more frequent with climate change (Trnka et al., 2014).

The inter-annual variability of grain yield recorded in both systems and both crops (Figure 2A) was mainly due to the effect of season climate. In fact, very low or very high yield observed in some years were common to both systems and both crops. The exception of the low yield of 2008 recorded for durum wheat but not for soft wheat was caused by the low seed vigour of durum wheat, not detected in the lab germination tests, but revealed then by slow and low emergence in the field. The higher grain yield observed across years for soft wheat compared to durum wheat in both systems indicates that the former species is better adapted to the environment of this inner region of Central Italy, where winter is quite cold and spring rainfall is generally sufficient to support water requirements for most of the grain-filling phase. The lower grain yield and protein content observed in the organic system for both species (Figure 2) is mainly to be ascribed to a lower $\mathrm{N}$ availability, while weeds were always successfully controlled in both systems and crops (Graziani et al., 2012). The top dressing of mineral $\mathrm{N}$ at tillering and pre-shooting in the conventional system was much effective compared to the pre-sowing application of poultry manure in the organic system, and in particular, the second application guaranteed $\mathrm{N}$ availability during grain filling with consequent increase in protein content. The strict negative correlation between grain yield and cumulated winter rainfall (Figure 3) confirms that, in Mediterranean climates with rainy win-
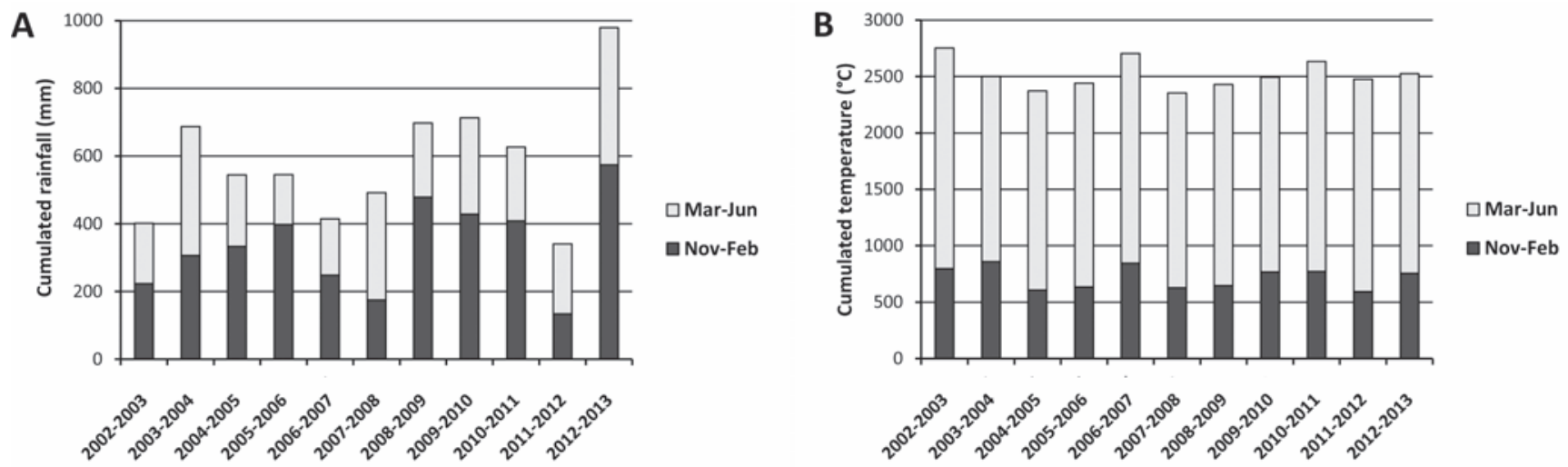

Figure 1. Cumulated rainfall (A) and temperature (B) from 1 November to 30 June in every year of wheat cultivation between $2002 / 2003$ and $2012 / 2013$. 


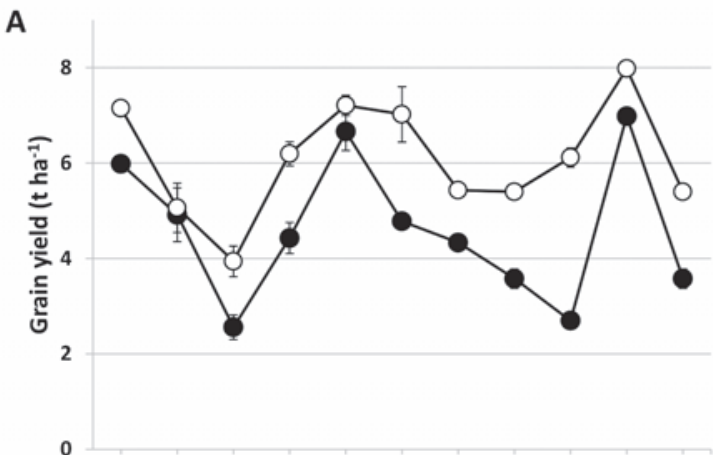

20032004200520062007200820092010201120122013

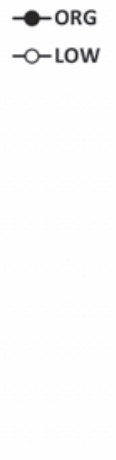

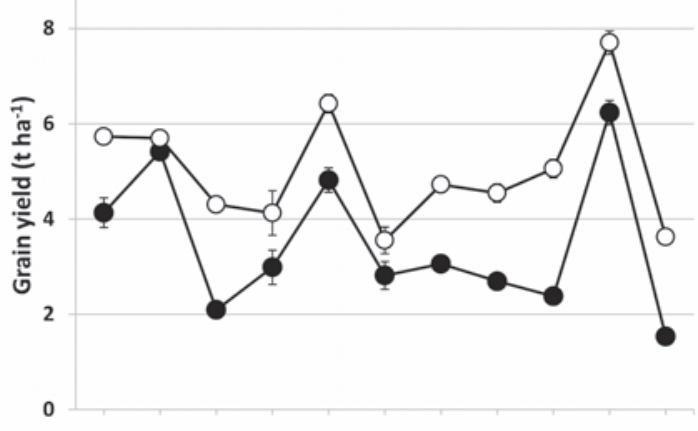

20032004200520062007200820092010201120122013

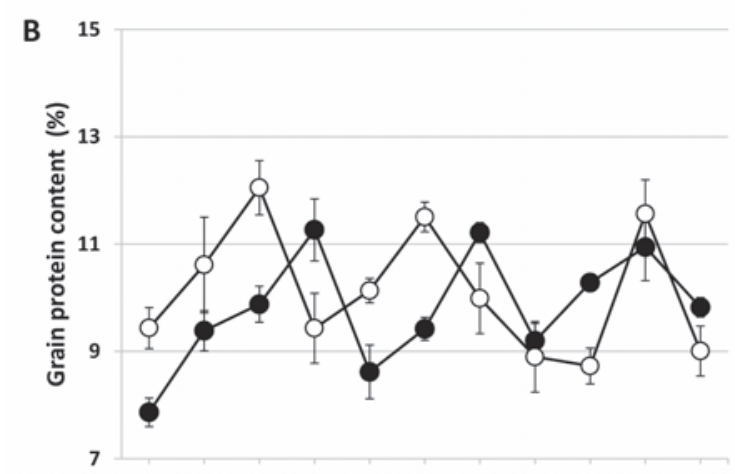

20032004200520062007200820092010201120122013
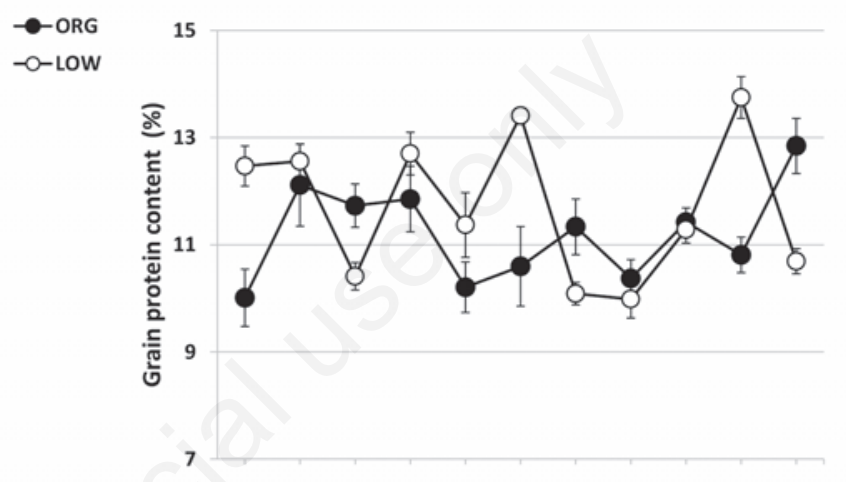

20032004200520062007200820092010201120122013

Figure 2. Grain yield ( $t$ ha $^{-1}$ of d.m.) (A) and protein \% content (w:w) (B) for soft wheat (left) and durum wheat (right) in the organic $(\mathrm{ORG}=$ full circles) and the conventional low input (LOW = empty circles) system across years 2002/2003-2012/2013. Vertical bars represent \pm 1 standard error of the mean.
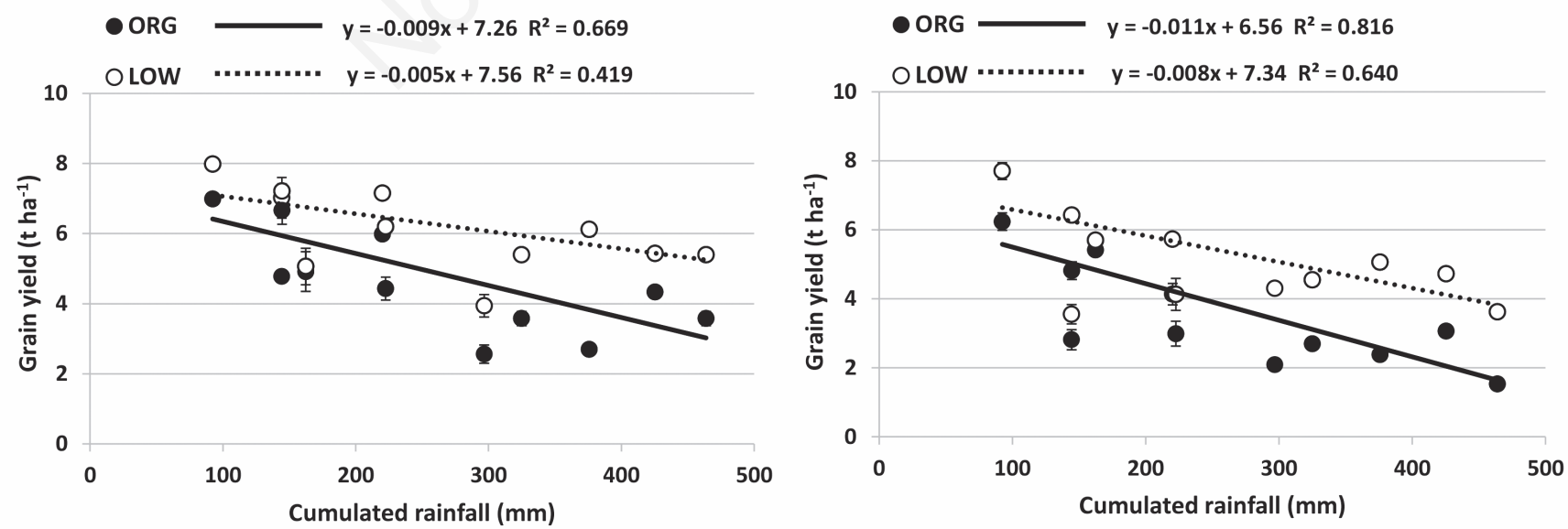

Figure 3. Relationship between grain yield ( $\left(\mathrm{ha}^{-1}\right.$ of d.m.) and cumulated rainfall $(\mathrm{mm})$ in the period November-February for soft wheat (left) and durum wheat (right) in the organic (ORG $=$ full circles, solid line) and the conventional low input (LOW $=$ empty circles, dotted line) system across years 2002/2003-2012/2013. Vertical bars represent \pm 1 standard error of the mean. 
ters, a late top dressing of $\mathrm{N}$ can represent a rational strategy to prevent $\mathrm{N}$ from leaching (Tosti et al., 2016), although late $\mathrm{N}$ availability contributes more to grain quality than to grain yield (Tosti and Guiducci, 2010; Blandino et al., 2015). The choice not to supply $\mathrm{N}$ as top dressing in the organic system was based on the evidence that organic fertilisers available for this purpose would have been much expensive and not much effective (Mayer et al., 2015; Tosti et al., 2016). At present, the only suitable alternative for a late supply of $\mathrm{N}$ in organic wheat seems a temporary intercropping between the cereal and a legume species with legume killing in late winter, a strategy that has been demonstrated to prevent $\mathrm{N}$ leaching and increase grain protein but not appreciably grain yield (Tosti and Guiducci, 2010; Tosti et al., 2016).

A lower yield was reported in several studies where wheat was grown organically (De Ponti et al., 2012; Migliorini et al., 2014; Mayer et al., 2015; Mazzoncini et al., 2015). One might object that our lower yield had to be expected because of the lower $\mathrm{N}$ rate (40 vs $80 \mathrm{~kg} \mathrm{~N} \mathrm{ha}{ }^{-1}$ ) used in the organic system. However, the same approach was followed by most of Authors above as it is widely accepted that a simplistic substitutional approach based on replace-
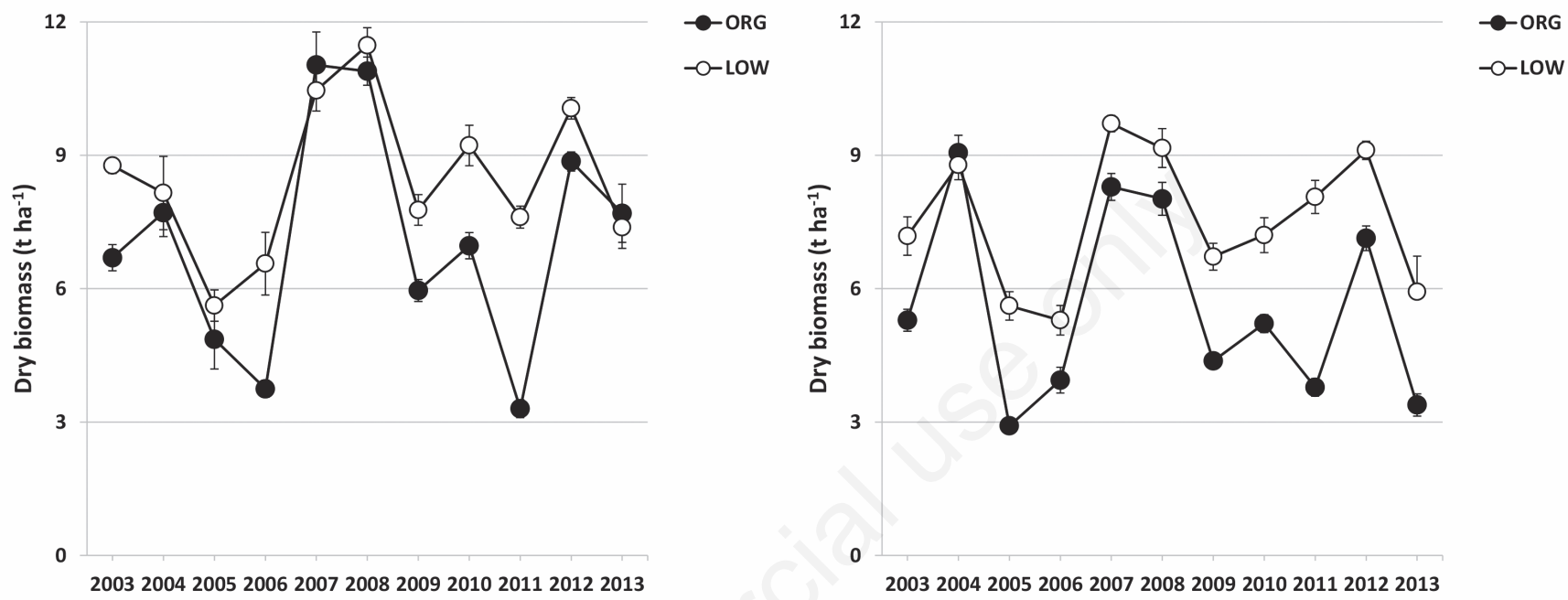

Figure 4. Amount of biomass ( $\mathrm{t} \mathrm{ha}^{-1}$ of d.m.) supplied to the soil (i.e., total above ground biomass included weeds plus organic fertiliser biomass minus grain biomass) for soft wheat (left) and durum wheat (right) in the organic (ORG = full circles) and the conventional low input (LOW = empty circles) system across years 2002/2003-2012/2013. Vertical bars represent \pm 1 standard error of the mean.
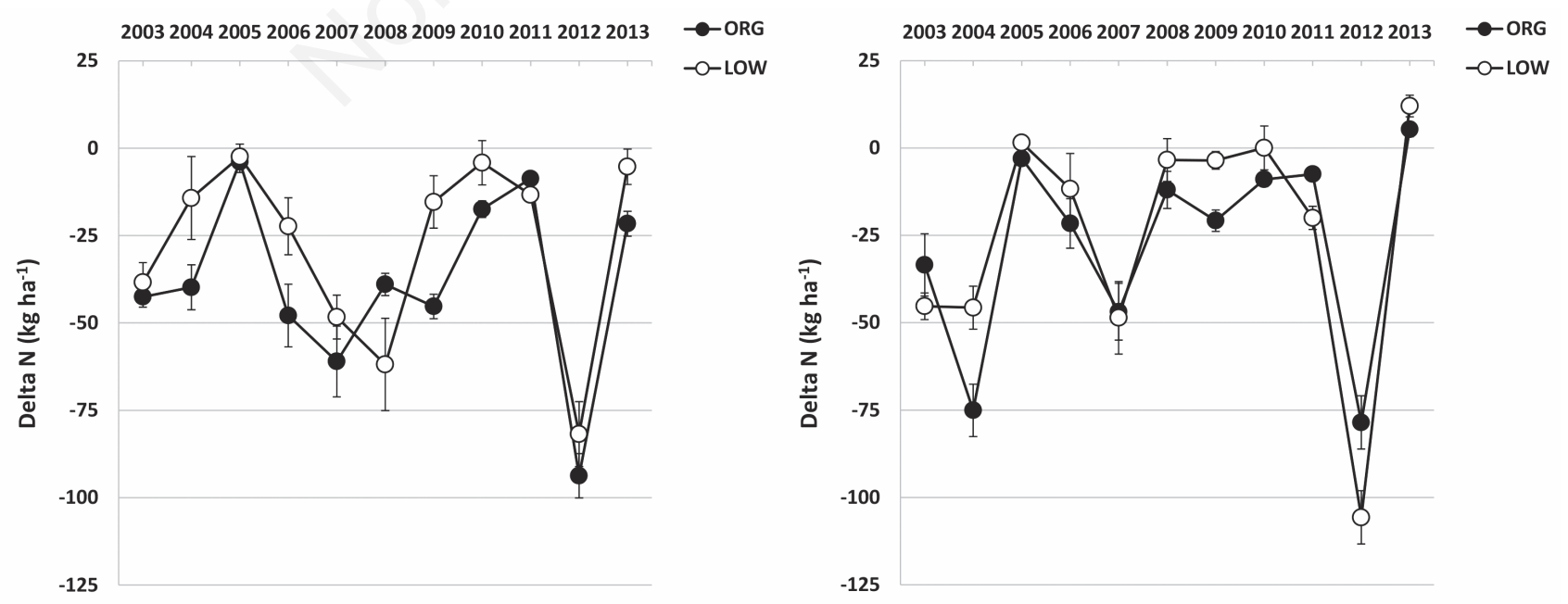

Figure 5. Delta $\mathrm{N}$ (i.e., fertiliser-N minus $\mathrm{N}$ removed with grain yield) for soft wheat (left) and durum wheat (right) in the organic $(O R G=$ full circles) and the conventional low input ( $L O W=$ empty circles) system across years 2002/2003-2012/2013. Vertical bars represent \pm 1 standard error of the mean. 

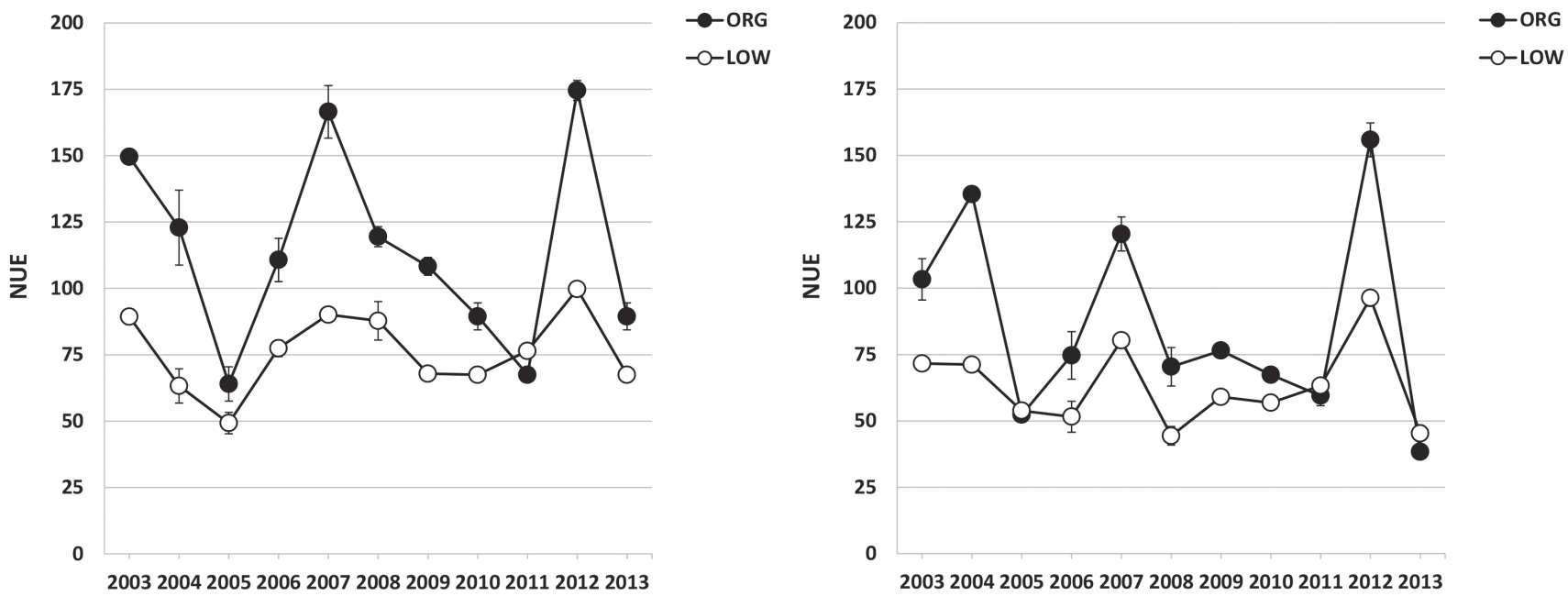

Figure 6. Nitrogen use efficiency (NUE, kg of grain dry matter per kg of fertiliser-N) for soft wheat (left) and durum wheat (right) in the organic $(\mathrm{ORG}=$ full circles) and the conventional low input (LOW $=$ empty circles) system across years 2002/2003-2012/2013. Vertical bars represent \pm 1 standard error of the mean.

ment of conventional inputs with equal amounts of inputs allowed for organic farming should be avoided (Darnhofer et al., 2010). The challenge of our organic $v s$ conventional low-input LTE, as it is for many other LTEs elsewhere, was to develop a more $\mathrm{N}$ self-sufficient organic system compared to the conventional one, relying on an improved $\mathrm{N}$ husbandry along the whole rotation (Thorup-Kristensen, 2002). In the BIOSYST rotation, wheat was supposed to benefit from the ex novo legume $\mathrm{N}$ provided by green manures before the preceding summer vegetable, and, in the meanwhile, wheat should have contributed to prevent $\mathrm{N}$ leaching in fall-winter (Thorup-Kristensen et al., 2012; Mayer et al., 2015). Actually, Thorup-Kristensen (2010) proposed to use minimally fertilised cereals to clean up the $\mathrm{N}$ left by vegetable crops. The importance of this measure would decrease passing from shallow-rooted short-season crops like lettuce (Tei $e t$ $a l ., 2000,2003$ ), to very wide-spaced crops like melon (Farneselli $e t$ al., 2015), to deeper-rooted and denser (compared to melon) crops like processing tomato, which was found to have quite high $\mathrm{N}$ uptake efficiency at low $\mathrm{N}$ rates (Tei et al., 1999, 2002). Data reported by Farneselli et al. $(2013,2015)$ for this same LTE indicate that only organic melon often left higher residual $\mathrm{N}$ compared to the conventional crop, while the opposite was recorded in most cases for tomato, and anyway differences were variable and not univocal across years. On the other hand, since legume-non legume intercrops were used for green manures, the $\mathrm{N}$ release from incorporated biomass was likely slowed and in part could have occurred during the wheat cycle (Quemada et al., 2004; Justes et al., 2009), contributing to its growth. A low release rate from legume-non-legume green manure biomass was actually observed in our experimental environment (Benincasa et al., 2010; Tosti et al., 2012).
The low return of biomass to the soil (Figure 4) and the negative delta N (Figure 5) recorded for both crops in both systems confirm that wheat-based cropping systems imply a progressive decrease of soil fertility unless appropriate rotation and management of soil $\mathrm{N}$ are adopted (Congreves et al., 2014). This means that the $\mathrm{C}$ and $\mathrm{N}$ pools of the system need to be built during the other rotation phases. Considering that crop residues for either wheat or maize or vegetables (Farneselli et al., 2013; 2015) were generally lower in the organic than in the conventional system and that the use of livestock manure was very limited in the former, green manures represented the only rotation phase to make a compensation (Thorup-Kristensen et al., 2012). The use of legume-non-legume intercrops represented a good measure to supply relevant amount of biomass and $\mathrm{N}$ with slow release rate (Benincasa et al., 2010; Tosti et al., 2010), which is known to play an important role for the recoupling of $\mathrm{C}$ and nutrient cycles (Drinkwater and Snapp, 2007). A higher long-term fertility of organic systems has been documented by many authors (Kuo et al., 1997; Berntsen et al., 2006; Mayer et al., 2015), included Mazzoncini et al. (2010) and Migliorini et al. (2014) working in Central Italy with vegetable-less rotations.

The higher $\mathrm{N}$ use efficiency of wheat in the organic system was expected, given the lower fertiliser $\mathrm{N}$ rate adopted with respect to the conventional system, since the NUE is known to negatively correlate with $\mathrm{N}$ rate (Fageria and Baligar, 2005). Moreover, the legume-nonlegume intercrop biomass supplied to the soil with green manuring likely implied some late $\mathrm{N}$ supplementation not accounted for in terms of $\mathrm{N}$ rate, which could have contributed to the higher NUE. The values of nitrogen use efficiency observed in our organic wheat are consistent with those reported by Mayer et al. (2015). 


\section{Conclusions}

In our experimental conditions, both soft wheat and durum wheat yielded less in the organic than in the conventional system and gave grains with lower protein content, used the supplied N more efficiently (on a marketable yield dry matter basis) and caused higher depletion of soil N. The main limitation for organic crops was the low $\mathrm{N}$ availability, not counterbalanced by the supposed residual effect of green manuring carried out before the preceding summer vegetable. In the conventional system, the chance to split the rate by using mineral fertilisers allowed to prevent leaching in fall-winter and guaranteed some $\mathrm{N}$ availability in spring.

Our experiment confirms that winter wheat can help reducing $\mathrm{N}$ leaching in fall winter but needs to be included in rotations with $\mathrm{N}$ building crops like green manures with legume species.

\section{References}

Benincasa P, Tosti G, Tei F, Guiducci M, 2010. Actual N availability from winter catch crops used for green manuring in maize cultivation. J. Sust. Agric. 34:705-23.

Berntsen J, Olesen J, Petersen B, Hansen E, 2006. Long-term fate of nitrogen uptake in catch crops. Eur. J. Agron. 25:383-90.

Blandino M, Vaccino P, Reyneri A, 2015. Late-season nitrogen increases improver common and durum wheat quality. Agron. J. 107:680-90.

Boldrini A, Benincasa P, Gigliotti G, Businelli D, Guiducci M, 2008. Effects of an organic and a conventional cropping system on soil fertility. pp 324-327 in Proc. $2^{\text {nd }}$ ISOFAR Conference, June 18-20, Modena, Italy. Organic e-prints ID number 12381.

Boldrini A, Benincasa P, Tosti G, Tei F, Guiducci M, 2007. Apparent N balance in organic and conventional low input cropping system. pp 264-267 in Proc. $3^{\text {rd }}$ International QLIF Congress, 20-23 March 2007, Hohenheim, Germany. Organic e-prints ID number 9885.

Congreves KA, Smith JM, Németh DD, Hooker DC, Van Eerd LL, 2014. Soil organic carbon and land use: processes and potential in Ontario's long-term agro-ecosystem research sites. Can. J. Soil Sci. 94:317-36.

Darnhofer I, Lindenthal T, Bartel-Kratochvil R, ZollitshW, 2010. Conventionalisation of organic farming practices: from structural criteria towards an assessment based on organic principles. A review. Agron. Sust. Dev. 30:67-81.

De Ponti T, Rijk B, van Ittersum MK, 2012. The crop yield gap between organic and conventional agriculture. Agric. Syst. 108:19.

Drinkwater LE, Snapp SS, 2007. Nutrients in agroecosystems: rethinking the management paradigm. In: DL Sparks (Ed.), Advances in agronomy. Academic Press, London, UK, pp 163-186.

European Commission, 1991. Council Regulation (EEC) No 2092/91 of 24 June 1991 on organic production of agricultural products and indications referring thereto on agricultural products and foodstuffs. In: Official Journal, L 198, 22/7/1991, pp 1-15.

European Commission, 1992. Council Regulation (EEC) No 2078/92 of 30 June 1992 on agricultural production methods compatible with the requirements of the protection of the environment and the maintenance of the countryside. In: Official Journal, L 215, 30/7/1992, pp 85-90.

Fageria NK, Baligar VC, 2005. Enhancing nitrogen use efficiency in crop plants. Adv. Agron. 88:97-185

Farneselli M, Benincasa P, Bonciarelli U, Tosti G, Tei F, Guiducci M,
2015. Yield and apparent dry matter and nitrogen balances for muskmelon in a long-term comparison between an organic and a conventional low input cropping system. Ital. J. Agron. 10:117-23.

Farneselli M, Benincasa P, Tosti G, Pace R, Tei F, Guiducci M, 2013. Nine-year results on maize and processing tomato in an organic and in a conventional low input cropping system. Ital. J. Agron. 8:9-13.

Fließbach A, Oberholzer HR, Gunst L, Mäder P, 2006. Soil organic matter and biological soil quality indicators after 21 years of organic and conventional farming. Agric. Ecosys. Environ. 118:273-84.

Gabriel JL, Munoz-Carpena R, Quemada M, 2012. The role of cover crops in irrigated systems: Water balance, nitrate leaching and soil mineral nitrogen accumulation. Agric. Ecosyst. Environ. 155:50-61.

Graziani F, Onofri A, Pannacci E, Tei F, Guiducci M, 2012. Size and composition of weed seedbank in long-term organic and conventional low-input cropping systems. Eur. J. Agron. 39:52-61.

Hawkesford MJ, 2014. Reducing the reliance on nitrogen fertilizer for wheat production. J. Cereal Sci. 59:276-83.

Justes E, Mary B, Nicolardot B, 2009. Quantifying and modelling C and $\mathrm{N}$ mineralization kinetics of catch crop residues in soil: parameterization of the residue decomposition module of STICS model for mature and non-mature residues. Plant Soil 325:171-85.

Kuo S, Sainju UM, Jellum EJ, 1997. Winter cover cropping influence on nitrogen in soil. Soil Sci. Soc. Am. J. 61:1392-9.

Mayer J, Gunst L, Mäder P, Samson M-F, Carcea M, Narducci V, Thomsen IK, Dubois D, 2015. Productivity, quality and sustainability of winter wheat underlong-term conventional and organic management in Switzerland. Eur. J. Agron. 65:27-39.

Mazzoncini M, Antichi D, Silvestri N, Ciantelli G, Sgherri C, 2015. Organically vs conventionally grown winter wheat: effects on grain yield, technological quality, and on phenolic composition and antioxidant properties of bran and refined flour. Food Chem. 175:445-51.

Mazzoncini M, Canali S, Giovannetti M, Castagnoli M, Tittarelli F, Antichi D, Nannelli R, Cristani C, Barberi P, 2010. Comparison of organic and conventional stockless arable systems: a multidisciplinary approach to soil quality evaluation. Appl. Soil Ecol. 44:124-32.

Migliorini P, Moschini V, Tittarelli F, Ciaccia C, Benedettelli S, Vazzana C, Canali S, 2014. Agronomic performance, carbon storage and nitrogen utilisation of long-term organic and conventional stockless arable systems in Mediterranean area. Eur. J. Agron. 52:138-45.

Quemada M, 2004. Predicting crop residue decomposition using moisture adjusted time scales. Nutr. Cycl. Agroecosyst. 70:283-91.

Tei F, Benincasa P, Guiducci M, 1999. Nitrogen fertilisation on lettuce, processing tomato and sweet pepper: yield, nitrogen uptake and the risk of nitrate leaching. Acta Hort. 506:61-7.

Tei F, Benincasa P, Guiducci M, 2000. Effect of nitrogen availability on growth and nitrogen uptake in lettuce. Acta Hort. 533:385-92.

Tei F, Benincasa P, Guiducci M, 2002. Effect of $\mathrm{N}$ availability on growth, $\mathrm{N}$ uptake, light interception and photosynthetic activity in processing tomato. Acta Hort. 571:209-13.

Tei F, Benincasa P, Guiducci M, 2003. Critical nitrogen concentration in lettuce. Acta Hort. 627:187-94.

Thorup-Kristensen K, 2002. Utilising differences in rooting depth to design vegetable crop rotations with high nitrogen use efficiency (NUE). In: R Booij, J Neeteson (Ed.), Proc. Workshop Eco. Fertilization Veg. Acta Hort. 571:249-54.

Thorup-Kristensen K, 2010. Nitrogen use efficiency in organic and conventional vegetable rotations - measured and model simulated results. Proccedings of the IV ISHS International Symposium on 
Ecologically Sound Fertilization Strategies for Field Vegetable Production, Malmo, Sweden. Acta Hort. 852:171-6.

Thorup-Kristensen K, Dresboll DB, Kristensen HL, 2012. Crop yield, root growth, and nutrient dynamics in a conventional and three organic cropping systems with different levels of external inputs and $\mathrm{N}$ re-cycling through fertility building crops. Eur. J. Agron. 37:66-82.

Tosti G, Benincasa P, Farneselli M, Guiducci M, 2016. Nitrogen fertilization strategies for organic wheat production: crop yield and nitrate leaching. Agron. J. [In press].

Tosti G, Benincasa P, Farneselli M, Pace R, Tei F, Guiducci M, ThorupKristensen K, 2012. Green manuring effect of pure and mixed barley - hairy vetch winter cover crops on maize and processing tomato N nutrition. Eur. J. Agron. 43:136-46.

Tosti G, Benincasa P, Guiducci M, 2010. Competition and facilitation in hairy vetch-barley intercrops. Ital. J. Agron. 5:239-48.

Tosti G, Guiducci M, 2010. Durum wheat-faba bean temporary intercropping: Effects on nitrogen supply and wheat quality. Eur. J. Agron. 33:157-65.

Trnka M, Rötter RP, Ruiz-Ramos M, Kersebaum KC, Olesen JE, Žalud Z, Semenov MA, 2014. Adverse weather conditions for European wheat production will become more frequent with climate change. Nature Climate Change 4:637-43.

Watson CA, Atkinson D, Gosling P, Jackson LR, Rayns FW, 2002. Managing soil fertility in organic farming systems. Soil Use Manage. 18:239-47.

Wortman SE, Galusha TD, Mason SC, Francis CA, 2012. Soil fertility and crop yields in long-term organic and conventional cropping systems in Eastern Nebraska. Renew. Agr. Food Syst. 27:200-16. 